Цімох Наталія Іванівна,

доцент кафедри тележурналістики, дикторів та ведучих телепрограм, Київський національний університет культури імистецтв

\title{
ПЕРСОНІФІКАЦІЯ ІНФОРМАЦІЇ ТА ПЕРСОНОФІКОВАНИЙ ОБРАЗ ВЕДУЧОГО ЯК НЕВІД'СМНА СКЛАДОВА УСПІХУ ТЕЛЕВІЗІЙНОЇ ПРОГРАМИ
}

Розглянуто інформачійний жанр інтерв'ю, в якому персоніфікація інформащії невід 'ємна від особистості. Лише завдяки процесу індивідуального переосмислення вона в тому чи іншому вигляді потрапляє до глядача. Саме від иьього прочесу залежить успіх телевізійної програми, телевізійного каналу і самого журналіста. 3 іншого боку, інтерв'ю - різноманітний $і$ непростий жанр, який займає неоднозначну позицію, зокрема в жанровій системі.

Ключові слова: телебачення, жанр, інтерв'ю, персоніфікація, інформачія.

Рассмотрен информационный жанр интервью, в котором персонифицированная информация неотделима от личности. Только благодаря проиессу индивидуального переосмысливания она, в том или ином виде, попадает к зрителю. Именно от этого прочесса зависит успех телевизионной программы, телевизионного канала и самого журналиста. Интервью - разнообразный и непростой жанр, который занимает неоднозначную позицию, в частности - в жанровой системе.

Ключевые слова: телевидение, жанр, интервью, персонификаџия, информащчя.

Is considered information genre interview in which personal information is inseparable from the individual, because the individual only through the process of rethinking it in one form or another goes to the viewer. It is from this process depends on the success of the television program of the television channel and journalist. On the other hand, the interview - diverse and challenging genre that occupies an ambiguous position, in particular - in the genre system.

Key words: TV genre, interviews, personification, information.

Актуальність теми дослідження визначається місцем, яке займає інтерв’ю у складній і різноманітній системі жанрів. Інтерв’ю (англ. interview - букв. «зустріч, бесіда» від лат. inter - «між, поміж» - префікс, що має значення взаємодії, взаємонаправлення, перебування в контакті. Це бесіда, вибудована за певним планом через безпосередній контакт інтерв'юера з респондентом з обов'язковою фіксацією відповідей. У зв'язку із цим здається доцільним не тільки визначити поняття «інтерв'ю» і його місце в системі журналістських жанрів, але і показати, що невід'ємною складовою успіху будь-якої програми, $є$ персоніфікація інформації та персоніфікований образ телевізійного інтерв'юера.

«Однією з найактивніших форм комунікації в наші дні стає усна публічна мова і в першу чергу - публічний діалог, найбільш затребуваним типом публічного діалогу в 
наші дні став жанр інтерв'ю, що виступає в двох своїх різновидах, інтерв'ю звукове та інтерв'ю друковане», зазначає дослідниця О. Голанова, міркуючи про різноманіття комунікативних ситуацій в сучасній дійсності [3, с. 343]. Інтерв'ю як складова системи засобів масової комунікації займає одну з найвищих позицій по частоті використання і техніці виконання, тому нині воно знаходиться в центрі уваги багатьох досліджень.

Здебільшого мовний жанр інтерв’ю в лінгвостилістиці досліджували в контексті мовознавчого аналізу загальних тенденцій розвитку стилю масової інформації і як особливий вияв його жанрових форм: Г. Солганик, В. Костомаров, В. Вакуров, М. Кохтєв, М. Кожина, Л. Шевченко, С. Єрмоленко, С. Чемеркін, М. Черепахов, С. Берєснєв, С. Потапенко, К. Серажим та ін. Також у лінгвостилістичному аспекті жанр інтерв'ю опосередковано досліджували з позиції лінгвістичного вивчення мовної структури монологічного й діалогічного текстів: І. Гальперин, Т. Дрідзе, С. Іванчикова, Р. Будагов, Н. Шумарова, В. Матезіус, Л. Кайда, В. Кухаренко, В. Корнєєв, З. Тухарелі та ін. Аналізувалася мова жанру, частково - особливості архітектоніки і системи кореляцій в тексті. Окрему групу наукових розвідок із питань специфіки функціонування інтерв'ю як методу й жанру становлять журналістські дослідження В. Сиченкова, О. Тертичного, В. Тищенко, В. Горбачук, М. Лукіна, Т. Шумишина, Д. Вовчок, М. Подолян, В. Карпенко та ін. Варто зауважити, що головним критерієм цих досліджень став аналіз мовної специфіки інтерв'ю, а його методологічно-функціональне обгрунтування в контексті професійної діяльності журналістів, персоніфікація інформації та персоніфікований образ телевізійного інтерв'юера, як невід'ємна складова успіху будь-якої програми, дослідженим не було. Кожна особа, акумулюючи інформацію, так чи інакше персоніфікує їі, свідомо чи підсвідомо прагне переповісти співрозмовнику, додаючи до неї власні емоції і думки, співпереживаючи і співвимірюючи їі. Персоніфікована інформація невід'ємна від особистості, адже лише завдяки процесу індивідуального переосмислення, вона в тому чи іншому вигляді потрапляє до глядача. Тому, було прийнято рішення дослідити персоніфікацію інформації та персоніфікований образ ведучого в телевізійному жанрі інтерв'ю.

Мета: розглянути жанр інтерв'ю на телебаченні як невід'ємну складову розвитку сучасного медіа простору, розкрити комунікативні стратегії ведення інтерв'ю, з’ясувати, як персоніфікація інформації та персоніфікований образ телевізійного інтерв'юера впливають на успіх будь-якої програми.

Подача інформації на телебаченні виражається внутрішньою силою кожного журналіста і ведучого телеканалу, який звертається до аудиторії та запрошеного гостя, а саме - персоніфікацією інформації. Найголовніше на телебаченні - це персоналії, адже одноманітні професіонали знижують рейтинг каналу. Вербальне спілкування в кадрі викликає у глядача довіру або навпаки - відчуженість до ведучого. Тому, невід'ємною складовою успіху будь-якої програми є персоніфікація інформації та персоніфікований образ телевізійного інтерв'юера.

Одним із перших телевізійних дослідників, який помітив тенденцію до персоніфікації на телебаченні, був Володимир Саппак. У своїй книзі «Телебачення і ми» він перераховує і характеризує деякі з властивостей, що дозволяють говорити про персоніфікацію телевізійноїінформації: документальність телебачення, імпровізаційність 
і інтимність телевізійного спілкування людини в кадрі з телеглядачем. Це ті «кити», на яких грунтуються основи персоніфікації і кредиту довіри телеаудиторії до ведучого інтерв'юера. Саме тому, незважаючи на відносно недовгу історію існування і розвитку телебачення, воно стало для багатьох одним із найбільш достовірним, а нерідко і найавторитетнішим джерелом інформації. Інформації, яка прозвучала з телеекрана, звикли беззастережно вірити цілі покоління. І хоча з початку демократичних процесів у нашій країні пройшло вже більше 20 років, аргумент «сказали по телевізору» залишається одним із найвагоміших для дуже великої кількості людей. Саме ця властивість телебачення - здатність викликати довіру ? дозволила зробити телеекран інструментом маніпулювання громадською думкою, свідомістю людей [9].

Нині персоніфікація інформації представлена процесом, який широко поширився в сучасному українському і зарубіжному телевізійному мовленні. Характерною рисою українського телебачення $\epsilon$ цілеспрямований вплив на масову свідомість і формування громадської думки у відповідності з політикою каналу. Персоніфікований образ телевізійного інтерв’ юера - найбільш зручна фігура для виконання цих завдань. Щоб досягти максимального ефекту своєї діяльності тележурналісти використовують різні прийоми, виразні засоби, мовні тактики.

Телевізійна комунікація вимагає встановлювати особистісні контакти аудиторії 3 комунікатором, щоб скласти судження про нього і про цінності його повідомлення. Саме цим і пояснюється значення і привабливість для аудиторії телевізійної інформації, персоніфікованої (тобто уособленої) її автором і учасниками подій.

Ведучий повинен сам представляти себе глядачеві як партнера у спілкуванні. Під взаємодією ведучого із аудиторією варто розуміти створення можливості наблизитися до ситуації реального спілкування із глядачем. Оскільки глядацька аудиторія сприймає телевізійну інформацію не лише опосередковано через ведучого (як інформацію проблемну, так і інформацію розважального характеру), а й через його особистість, то неабиякого змісту набуває персоніфікація інформації. Питання зв'язку інформації 3 тим, як на їі подання в ефірі впливає особистість ведучого є досить важливим. Інколи однісї появи ведучого достатньо для того, щоб глядацька увага зосередилася на ньому. I навпаки, людина, яка говорить, здавалося б, цікаві й потрібні речі, не може викликати глядацького інтересу. Ведучий - інтерв'юер телевізійної програми, безумовно, є представником певної соціальної групи, і його взаємодію із аудиторією можна розглядати як «представницьке спілкування».

Знайома людина в кадрі є для глядача, насамперед, орієнтиром у багатому світі телевізійних програм, завдяки чому кожна іï поява супроводжується цікавою для глядача інформацією. Найбільш високий рівень персоніфікації тоді, коли інтерв’юер, він же журналіст, виступає як учасник екранізованої дії- бере інтерв'ю, організовує дискусію між двома сторонами, проводить репортаж - розслідування, тим самим стає об'єктом співчутливої ідентифікації. I тут ведучий має бути дуже підготовленим до інтерв'ю, адже інтерв'ю - це заздалегідь прорахована тактична схема. І вдале інтерв'ю неможливе без заздалегідь прогнозованих для себе «несподіваних» поворотів розмови.

Г. Лазутіна наголошує на тому, що до зустрічі з опонентом інтерв'юеру треба дуже ретельно готуватися. Навіть ретельніше, ніж до випуску новин, оскільки будь- 
яка форма діалогу повинна бути живою, містити активність обох сторін. У зустрічі вирішальним моментом має бути почуття і усвідомлення відповідальності за кожне сказане слово [7, с. 72]. Не слід забувати, що навіть добре підготовлене інтерв'ю може прийняти неочікувану форму. При підготовці до інтерв’ю на перше запитання журналіст повинен передбачити дві відповіді: позитивну і негативну. Від відповіді залежить кожне наступне запитання, на яке знову ж таки треба передбачити дві протилежні відповіді. Можна зобразити схему, схожу на дерево, де на кожне запитання очікується одна 3 двох відповідей [6].

Еріх Фромм у своїй праці «Анатомія людської деструктивності» зробив наступні висновки щодо потреб людини (усі вони є стратегічно важливими для сучасних 3МI): потреба у спілкуванні, потреба у творчості, пошук ідеального, потреба у відчутті безпеки життя, прагнення до уподібнення, пошук об'єкта поклоніння. Індивід живе у світі суперечливих мотивів, прагнень і очікувань. Йому необхідно співвідносити свою поведінку з персоніфікованим зразком: в основу персоніфікації, як правило, закладається психологічний тип обраної особистості, а також прагнення до освоєння світу. Людина тягнеться до пізнання, до осягнення себе через думки і погляди інших [12].

Для підтвердження вище наведеного дослідження Е. Фромма наведемо деякі приклади відомих імен: Володимир Шнейдеров, з особистістю якого довгий час асоціювалося телебачення загалом; Юрій Левітан: «Внимание! Говорит Москва» (в роки війни); Ігор Кирилов, ведучий програми «Время» (у 70-ті роки минулого століття, коли були ще не ведучі, а диктори, простіше було уявити телебачення без програми «Время», ніж Ігоря Кирилова без краватки).

У даний час персоніфікація інформації представлена процесом, який стрімко поширився в сучасному українському і зарубіжному телевізійному мовленні. Характерною рисою українського телебачення є цілеспрямований вплив на масову свідомість і формування громадської думки у відповідності з політикою каналу. Персоніфікований образ телевізійного інтерв'юера - найбільш зручна фігура для виконання цих завдань. Щоб добитися максимального ефекту своєї діяльності тележурналісти використовують різні прийоми, виразні засоби, мовні тактики.

Телевізійна комунікація вимагає встановлювати особистісні контакти аудиторії 3 комунікатором, щоб скласти судження про нього і про цінності його повідомлення. Саме цим і пояснюється значення і привабливість для аудиторії телевізійної інформації, персоніфікованої (тобто уособленої) її автором і учасниками подій.

Ведучий повинен сам представляти себе глядачеві як партнера у спілкуванні. Під взаємодією ведучого із аудиторією варто розуміти створення можливості наблизитися до ситуації реального спілкування із глядачем. Оскільки глядацька аудиторія сприймає телевізійну інформацію не лише опосередковано через ведучого (як інформацію проблемну, так і інформацію розважального характеру), а й через його особистість, то неабиякого змісту набуває персоніфікація інформації. Питання зв'язку інформації $з$ тим, як на ії̈ подання в ефірі впливає особистість ведучого є досить важливим. Інколи однієї появи ведучого достатньо для того, щоб глядацька увага зосередилася на ньому. І навпаки, людина, яка говорить, здавалося б, цікаві й потрібні речі, не може викликати глядацького інтересу. Ведучий - інтерв'юер телевізійної програми, безумовно, є 
представником певної соціальної групи, і його взаємодію із аудиторією можна розглядати як «представницьке спілкування».

Як показує телевізійна практика, відповідність іміджу жанрові й тематиці програми не лише важлива, а й необхідна. Оскільки порушення цієї вимоги призводить до непрофесійності передачі, дисгармонії між образом, поведінкою ведучого і тематикою програми, а найголовніше - до неприйняття з боку глядачів. Варто враховувати той факт, що імідж ведучого є, перш за все, комунікативною категорією, яку можна розділити на вербальну та невербальну. До вербального комунікативного іміджу відносять дикцію, артикуляцію, темпоритм і динаміку мовлення, інтелектуальні, граматичні показники, голос тощо. До невербального комунікативного іміджу ведучого належать міміка, жестикуляція, стиль одягу, зачіска, макіяж.

Потрібно пам'ятати, що, розділяючи імідж на дві комунікативні категорії, ми характеризуємо імідж ведучого в студії під час запису або прямого ефіру. Але не можна обмежувати імідж інтерв'юера тільки студією. Адже ведучий - це особа публічна, i після того, як вимикається камера, він так само, як і під час ефіру повинен намагатися дотримуватися усталеного іміджу, тоді довіра до нього глядачів тільки зростатиме.

М. Василенко наголошує на тому, що найвищий рівень персоніфікації - коли журналіста чекають на екрані заради нього самого, чекають як лідера, який вміє пояснити складні проблеми, як особистість значну в моральному, духовному плані [2, с. 52].

Місце ведучого в системі цінностей телебачення - одне 3 чільних, якщо не головне. Він як виразник багатьох думок і тенденцій, як постать, що уособлює різні інтереси, має володіти багатьма рисами. Варто зазначити, що «інтерв’юер», як окремий сегмент поліпрофесії, «тележурналіст» формувався за принципом подвійної конщептуалізації.

Ведучий - це творча людина, яка надзвичайно обізнана і постійно збагачує свої знання; це професіонал, який досконало володіє голосом, манерою поведінки, роботою із гостем в студії; це універсал, який може виконувати роботу журналіста, редактора, режисера і оператора, а отже, самостійно вирішувати поставлені завдання; це особистість, яку не можливо не слухати і яку б хотілося чути ще не раз; це відповідальний працівник, який дотримується всіх правил, встановлених у редакції чи компанії. Він має одного разу знайти себе і зробити знайдене привабливим. Володимир Познер - яскравий представник саме такого типу інтерв'юерів. Його телевізійна кар'єра розпочалася задовго до того, як простий глядач зробив Володимира Познера ведучим, якого найбільше з усіх колег журналістів цитують на теренах колишнього Радянського Союзу. І це недарма. Кожен випуск його програми «Познер» можна прирівняти до виходу в читацький світ «Збірки висловів і афоризмів», яка кожного наступного тижня поповнюється новим виданням. Герої його авторської програми готові розказати найбільш сокровенне і відкрити потаємні сторони свого відомого життя. «Познер»це програма-інтерв'ю.

На сучасному телебаченні більшість ведучих виступають у ролі інтерв'юера як частково (діалог під час ефіру) так і повністю ( як автор і ведучий цілої програми). Жанр інтерв'ю набув надзвичайної популярності, адже глядачам цікава особиста думка героїв програм, їхнє ставлення до тих чи інших проблем у суспільстві. Глядач хоче 
бачити «справжнє обличчя» відомої персони - ось головний критерій оцінки ведення інтерв'ю. Персоніфікація інтерв'юера, в свою чергу, допомагає глядачу зорієнтуватися на виборі програми: якщо ведучий викликає довіру, надає глядачеві усі відповіді на поставлені ним запитання до кінця інтерв'ю з обраним гостем у студії, то глядач сам буде очікувати на вихід програми в ефір. Для того, щоб глядацька аудиторія автоматично, але при цьому позитивно асоціювала інтерв'юера із певним типом програми, він повинен бути постійно готовим до нестандартних ситуацій, гострих відповідей, несподіваних поворотів діалогу.

О. Кашкіна говорить про те, що особистість ведучого, його фахові якості та вміння разом із усвідомленням поставлених перед ним завдань часто бувають визначальними для успіху програми [4, с. 9].

Знайома людина в кадрі є для глядача, насамперед, орієнтиром у багатому світі телевізійних програм, завдяки чому кожна іiі поява супроводжується цікавою для глядача інформацією. Найбільш високий рівень персоніфікації тоді, коли інтерв'юер, він же журналіст, є учасником екранізованої дії - бере інтерв’ю, організовує дискусію між двома сторонами, проводить репортаж-розслідування, тим самим стає об' єктом співчутливої ідентифікації. І тут ведучий має бути дуже підготовленим до інтерв'ю, адже інтерв'ю - це заздалегідь прорахована тактична схема. І вдале інтерв'ю неможливе без заздалегідь прогнозованих для себе «несподіваних» поворотів розмови.

О. Самарцев зазначає, що спілкування з кожною новою людиною ведучий програми ніколи не будуватиме за шаблоном попередньої, адже змінюються тема, рівень зацікавленості самого ведучого, особистість співрозмовника, враховується рівень слухацької активності і, як результат всього цього, можливість непередбачуваного [8, с. 68]. У гостях «Познера» глядач постійно очікує на нові цікаві, але, попри все, відомі обличчя нашого часу. Рівень запрошених гостей варіюється від акторів, комедіантів, режисерів (тобто творчих людей) до персон, які створюють політичну історію. Жодну із його програм не можна назвати однаковою, або навіть схожою.

«Більшість людей, які зуміли досягти успіху в житті, вміють говорити, ? помічає «король ефіру» Ларі Кінг: «Не дивно, що правильним є і зворотне. Дорога до успіху в побуті або в професійній діяльності - вимощена розмовами» [5].

За 25 років виходу програми «LarryKingLive» він взяв інтерв’ю майже у 50 тисяч осіб. 25 років поспіль 3 понеділка по п’ятницю, в один і той же час, щодня Ларі робив своє шоу. І це було не шоу шоумена Ларі, а шоу Людини, якого інтерв’ював Ларі. Людина в студії була головною дійовою особою, а не просто королем підтяжок. За 25 років в ефipi CNN його програма не змінювала ні час виходу, ні ведучого, а тому потрапила до Книги рекордів Гіннесса. У самого Ларі стільки американських нагород, що навряд чи він сам може їх перерахувати. Нині ж Ларі Кінг - один із найвідоміших інтерв'юерів світу, якого по праву називають «королем інтерв’ ю».

Ще одним яскравим прикладом індивідуальності стала популярна американська ведуча Опра Уінфрі (Опра Гейл Вінфрі) - американська актриса і ведуча ток-шоу «Шоу Опри Вінфрі», найвпливовіша людина шоу-бізнесу в 2009 р. за версією журналу Forbes. Опра Вінфрі стала першою жінкою-репортером телебачення Нешвілу і, крім того, першим наймолодшим репортером. У 22 роки Опра вже працювала на телеканалі WJZ, 
що у Балтиморі. Із досвідом роботи телеведучою, у 30 років вона ризикує і відправляється до Чикаго, щоб розпочати роботу над ранковим ток-шоу. Опра Вінфрі так прийшлася до душі глядачам та телеканалу, що через рік ток-шоу перейменовують на «The Oprah Winfrey Show».

Шоу Опри Вінфрі вже 25 років в ефірі, це найбільш популярне шоу в Америці. У 140 країнах світу його дивляться біля 70 мільйонів осіб. Запорукою їі успіху і шаленої популярності стали: щирість, прагнення зробити світ кращим та відсутність страху перед новими горизонтами.

На особливу увагу серед сучасних телевізійних ведучих українського ефіру заслуговують такі особистості: Андрій Куликов - ведучий каналу ICTV, TCH, Українська служба Бі - Бі - Сi, Свобода слова (ICTV). Савік Шустер - автор і ведучий соціальнополітичного шоу «Шустер live» на каналі «3S.tv», генеральний продюсер продакшн компанії «Савік Шустер Студія». Свгеній Кісєльов - радянський, російський і український журналіст, радник директора Group DF Бориса Краснянського. Ганна Безуликукраїнська телеведуча, журналіст. Роман Чайка - український телеведучий, журналіст.

Багато дослідників, що освоюють для своїх професійних потреб методику глибокого інтерв'ю, визнають, що інтерв'ювання виявляється важчою справою, ніж вони спочатку припускали. Їх можна зрозуміти. Робота інтерв'юера вимагає постійної концентрації уваги і швидкої реакції. Інтерв'юер повинен правильно розуміти респондента, стежити безперервно за ходом його думки і одночасно фокусувати бесіду на проблемі дослідження. Усе це вимагає майстерності, навичок і дотримання методичних принщипів інтерв’ювання.

\section{Лimepamypa:}

1. Багиров Е. Г. Основы телевизионной журналистики / Е. Г. Багиров, Р. А. Борецкий, А. Я. Юровский. - Москва, 1987. - 224 с. 2. Василенко М. Динаміка розвитку інформаційних та аналітичних жанрів в українській пресі : монографія / М. К. Василенко. - Київ : Інститут журналістики КНУ імені Тараса Шевченка, 2006. - 238 с. 3. Голанова Е. И. Устный, публичный диалог: жанр интервью : текст / Е. И. Голанова // Русскийязыкконияа ХХ столетия. - [2 - е изд.] - Москва : 2000. - 480 с. 4. Кашкина О. В. Функциональный анализ самооценочных высказываний как средства вербализачии Я - кониепта : на материале интервью немецкой прессы. Текст : автореф. дис. канд. филол. наук / О. В. Кашкина. - Воронеж, 2005. - 24 с. 5. Кинг Л. Как разговаривать с кем угодно, когда угодно и где угодно /Л. Кинг. - Москва : АльпинаБизнес Букс. - 2006. -206 с. 6. Кукушкина О. В. Речевые Неудачи как продукт речемыслительной деятельности Текст : автореф. дис. д-ра филол. наук / О. В. Кукушкина. - Москва, 1998. - 76 с. 7. Лазутина Г. В. Основы творческой деятельности журналиста : [учеб. для студ. вузов, обучающихся по спец. «Журналистика»] / Лазутина Г. В. - [2-е изд., перераб. и доп.]. - Москва : Аспект Пресс, 2007. - 240 с. 8. Самариев О. Р. Актуальные проблемы телевизионной журналистики в условиях современного этапа информационно-компьютерной революиии. Текст. : автореф. дис. д-ра филол. наук / О. Р. Самариев. М., 1999. - 146 с. 9. Саппак В. Телевидение и мыл: Четыре беседы, Золотой фонд ТВ-литературы / В. Саппак. - Москва : Аспект Пресс. 2007. 10. Светана С. В. Телевизионная речь, функиии и структура / С. В. Светана. Москва, 1976. - 87 с. 11. Седов К. Ф. Дискурс и личность : эволючия коммуникативной компетенции. Текст. : монографія /К. Ф. Седов. - Москва : Лабиринт, 2004. - 320 с. 12. Фромм Е. Анатомія людської деструктивності / Е. Фромм. - Москва : АСТ, 2004. 